\title{
Narratives, Policies and Governance Influence Development of Sustainable Human-Nature Relationship Systems in Central but Subtle Ways
}

\author{
Jan Lynette Stanley \\ Julie Ann Wrigley Global Institute of Sustainability, Arizona State University, Tempe, USA
}

\section{Email address:}

jan.stanley@asu.edu

\section{To cite this article:}

Jan Lynette Stanley. Narratives, Policies and Governance Influence Development of Sustainable Human-Nature Relationship Systems in Central but Subtle Ways. International Journal of Law and Society. Vol. 4, No. 1, 2021, pp. 28-38. doi: 10.11648/j.ijls.20210401.14

Received: January 14, 2021; Accepted: January 25, 2021; Published: January 30, 2021

\begin{abstract}
As global attention increases to climate change, topics related to its causes, long-term effects, and associated issues grow in number and complexity. Once dominated by fossil fuels and alternatives to them, related discussions now include environmental justice and equity, cultural and environmental diversity, education, spiritual ecology, and complex systems to name a few. Rarely discussed is the critical, more basic, and less obvious role of Earth and culture's co-evolution and the central part this plays in individual and collective human identity formation. The longitudinal study reported here revealed the importance of these foundational development processes and their consideration in efforts toward more just, resilient and sustainable futures. A globally familiar situation, the proposed construction of a hydropower plant in a largely untouched area of Iceland's remote West Fjords, provided a material and internationally relevant focus for coordinated study of people and natural context and the meanings assigned in the course of their interaction. The findings strongly suggest that as we write laws, set policies, and create agreements at local, national and international levels, the processes of individual human development and earth-human co-evolution must receive focused consideration. Regulations and the types of relationships they support are important shapers of contexts that influence, in turn, personal, cultural and environmental directions and identities. Findings highlight also Homo sapiens' role, intentional or not, in the evolution of the species as we know it. Implications of the research extend from schooling to governance, economic policy, and the writing, interpretation and enforcement of laws. All are influenced by the stories we tell and meanings associated with them. Without that understanding and what it reveals about human-nature relationships, changes required for more durable and inclusive futures will be limited. Using methods of participatory research and ethnography, this research investigated human-nature relationships, how they develop and are interrupted in context, and the associated implications for addressing many issues surrounding climate change and its mitigation.
\end{abstract}

Keywords: Narrative and Meaning, Governance, Policy, Legal Interpretations, Human-Nature Systems, Sustainability

\section{Introduction}

As global attention increases to climate change, topics related to its causes, long-term effects, and associated issues grow in number and complexity. Once dominated by fossil fuels and alternatives to them, related discussions now include environmental justice and equity, cultural and environmental diversity, education, spiritual ecology, and complex systems to name a few. Rarely discussed is the critical, more basic, and less obvious co-evolution of Earth, culture, and individuals and the central part this plays in individual and collective human identity formation. The longitudinal study reported here revealed not only the importance of these foundational developmental processes in efforts toward sustainability but also the impact of governance, policy and legal practices on them. Findings suggest that new perspectives and considerations are necessary in order to support healthy, mutually responsive human-nature systems and thereby foster sustainable practices for a durable planet and humane, inclusive relationships among Earth's many life forms. Among these considerations are the stories and meanings associated with places and events [1].

In Iceland and globally, hydropower has been valued for many years as a renewable energy source. As losses associated 
with the damming of rivers grow, objections to hydropower accumulate and amplify. This is especially true now when wilderness areas, longtime homesteads, and established, viable ways of life are threatened by new dam construction. Related controversies are often extensive, emotional, and compounded by multiple local and outside interests. They continue, often escalating, across many years. Equitable resolution remains elusive. This was the situation surrounding a proposed hydropower plant on Hvalá, a river in Iceland's remote West Fjords.

Plans for the hydropower project, named Hvalárvirkjun, called for the construction of five or six dams and a power plant on a largely untouched highland heath just south of Hornstrandir Nature Preserve. This heath, Ófeigsfjarðarheiði, and much of the area adjacent to it have never been occupied and are seldom visited by humans. Some people appreciate the area's stark beauty and the psychological, spiritual and instructional value of Earth's few remaining untouched places. They speak also of the migratory birds and unique flora that are supported by the heath.

Many people who favor the hydropower plant see only rock on Ófeigsfjarðarheiði, where two of three to-be-harnessed rivers are located. The largest of these rivers and the location of the proposed powerplant is Hvalá. All are located in the sparsely populated Árneshreppur municipality within the Strandir region. People in the pro-dam group believe that sufficient water will remain to supply the rivers' dramatic, potentially tourist-attracting waterfalls and canyons. For this group and especially for the year-round residents of Strandir, this concern is secondary. The more immediate need is for a reliable supply of commerce-compatible electricity and roads that are passable year-round. Without electricity and access, neither farming, fishing nor businesses can continue or establish; the ongoing attrition from the area will accelerate. Few members of this widely dispersed, once thriving farming and fishing community remain now.

Local pro and con groups are keenly aware of the exclusion of the West Fjords from the effective electricity delivery system that powers the more heavily populated south and, also, from Iceland's main paved highway, "The Ring Road," that eases access around the rest of the country. The completion of a tunnel in late 2020 opened secondary roads in some of the West Fjords for year-round travel. These roads do not reach Strandir.

Across the seven years that I traveled and conducted research in the West Fjords, I watched the impact of such exclusion grow and felt with residents mounting anxiety as the economic viability of the region was impeded in multiple ways. The associated attrition continued despite repeated local efforts to revitalize this once resilient, food-producing region in ways that blend tradition and modern sustainable practices. Abandonment of the area is concerning at a time of growing global food insecurity and as small communities and localization demonstrate more promise for durable futures worldwide than the global, industrial-capitalism complex of large cities.

Residents of the West Fjords feel also the brunt of the urban-rural divide. Multiple residents told me "They [the people of the urban south] believe we all wear skins and horned helmets and carry spears." The meaning, of course, is that the people of the West Fjords are considered backward and ignorant by some - an unfair and untrue belief held among voters in the much more heavily populated, urban south. The population attrition that accompanies such marginalization is especially rapid and poignant in Strandir. It is accentuated, perhaps, by proximity to the Hornstrandir Nature Preserve, where attrition from that always sparsely populated area supported its transition to nature reserve. This situation and the possibility of loss of place is familiar in remote and rural locales worldwide.

When in 2013 I initiated ethnographic research into human affinity with natural place in the West Fjords, the hydropower controversy was less dominant in daily conversations than more immediate issues surrounding fishing quotas, the fisheries themselves and tourism's growing economic dominance and environmental impact. By 2019, the hydropower conflict had escalated both locally and nationally and had attracted international attention. I was intrigued initially by what seemed anomalous: The people of Iceland and especially the West Fjords had been strong conservators of nature and the stories embedded in land and sea. Yet, there were among this group many outspoken proponents of Hvalárvirkjun. I wondered how they resolved the apparent conflict and justified the lasting disruption of their meaningful spaces (termed "places" here). The specific local objections to the project were also of interest. I believed that somewhere between the two positions, I might find helpful perspective on human-nature relationships and factors that influence their development. I did not anticipate the resultant, fundamental changes to either my practice of social science or my broadened understanding of people, culture and natural place in interaction.

\section{A Familiar Situation}

\subsection{Gathering and Verifying Information}

In September 2019, my research focused on Standir and the developing story of Hvalárvirkjun. The initial plan was to gather and verify factual information as usual, but the futility of that approach seemed to grow with each conversation I had, each news report I read, and each official account or map I saw. Even the time of the developing story's beginning was disputed. Estimates ranged from three to forty years ago. Some confusion associated with long attention to the river of primary focus; Hvalá carries across impressive changes in elevation the greatest volume of water of all West Fjords rivers. Its potential for hydropower generation is hard to ignore.

One man who was involved in the project design and planning reported an initial start date shortly before the Icelandic banking collapse of 2008. According to him, plans were shelved then and resurrected in 2014 as the economy stabilized. One group acknowledged the project's seventeenth anniversary in April 2020. No one named for me an event or a 
decision that could be called the starting point, but preliminary work was evident on the land.

Some said permits had not been issued; others said they had. Still others said that the work proceeded on private land with landowner's permission, but some contested the alleged ownership of this land. It seemed clear that local permits were issued by Árneshreppur's governing council to allow construction for access and research purposes, but the fairness of the council elections was questioned. Environmental groups held that construction was not necessary for legitimate research in the area and was instead an illegal way around environmental protection.

Two weeks of intensive information gathering left me feeling like I had wandered into a multi-colored ball of rubber bands. Purported narrative facts seemed to stretch and change shape depending on who relayed them. Few worked together to form a clear, complete picture. Consistent verification of the narratives was equally illusive. One longtime research participant commented, "We don't know what's in the middle. We know what's at the beginning and what the end is supposed to be, but we don't know what's in the middle."

The middle did seem obscured by a tangle of hued, stretchable, not quite complete facts. Without the middle, a good decision about the project's desirability was not possible. Would it benefit the West Fjords as initially promised? Would the power supplied be of the quality required by manufacturing and other businesses? Would its transmission be reliable within the West Fjords and extend to all parts of the region? Or would most of the power go to the Reykjavík area for sale to foreign corporations who sought data storage in Iceland?

Lands and rivers had been destroyed before in Iceland to supply power to external interests. The Swedish company, HS Orka, that was heavily involved in at least one of those hydropower projects was behind the Hvalárvirkjun project also with $70 \%$ ownership of the local company (VesturVerk) that developed the plan originally. Verification of benefit to the West Fjords was as elusive as complete, clear information.

When I was warned that too many questions about the project could land me in the category "enemy of the West Fjords," my empathy increased with the people of the region and others worldwide who face similar daunting decisions for natural, cultural, and social places. The origins and dynamics of the conflict became as important as gathering narrative facts in these situations and to understanding the general failure worldwide of efforts to resolve such conflicts in ways that serve all resident species and the planet. A different approach to understanding the situation was indicated.

\subsection{Narrative, Story and Meaning}

Narrative facts are given interpretation and meaning as they assemble into stories. Personal and contextual experiences, beliefs, motivations and values guide story development and the meanings assigned in their telling [2]. More important than "facts" in understanding the situation were the differing meanings and beliefs revealed among the stories. Because meaning making and the experience of place are subjective in character, methods of narrative research, a type of participatory research, were used to explore the conflicts associated with Hvalárvirkjun.

Rigorous participatory research requires inclusion of researchers' own subjective experience as an important source of information. This information accompanies reports of findings to enable readers' evaluation and use of the research. The information is presented as first-person accounts of researchers' experience and observations. In this, participatory research differs necessarily from research that seeks objective answers to precise questions with discrete, measurable variables. Findings are reported below in a format consistent with narrative research.

Carefully selected individuals were enlisted as participants in the research. From them, I collected stories, histories, and interpretations surrounding the topic of interest. As the investigation progressed, personal convictions and interpretations slowly revealed the heart of this and similar conflicts. A tangled tale itself, this deeper story provided critical insights and possible solutions.

Four stories follow in the order that I discovered them. All were cross checked against news reports, historical accounts and reports from other individuals and group with an interest in the conflict. Three stories were collected from individuals who represented different positions on Hvalárvirkjun; one proponent, one opponent and one from the company that engineered and planned to build the dam. Importantly, the story of Hvalárvirkjun cannot be framed exclusively around people. The fourth story is told from the land, rivers, sea, histories and all that inhabit them - animals, plants, geologies, geographies, legends and stories. These have made people and place strongly who they are.

\section{Findings in Four Stories}

\subsection{Lára's Story}

Lára was a fulltime resident of Reykjavík, a nationally known opponent of Hvalárvirkjun, and a landowner in Árneshreppur. She grew up in Eyvindarfjörður immediately north of Ófeigsfjörður and the proposed power plant, and she maintained close ties to this land that remained her ancestral place. Despite distance and poor road conditions, Lára returned to stay in her childhood home several times each year. As in earlier times, the family kept a boat there to reach roadless areas of their land that are difficult to reach on foot.

Our conversation began with an orientation to the area using maps and an Árneshreppur brochure that Lára provided. She recalled growing up with siblings on Eyvindarfjörður and walking or traveling by boat to parts of it for picnics and recreation or to obtain household necessities and attend school. The brochure pictured Drangaskörd where a series of basalt monoliths pointed skyward like boney plates on a dragon's tail. She described family boat trips there saying, "Here is this little ness [peninsula], and Drangá [a river] is here also...I love this. This is the loveliest place in the earth. Here is nothing. It's lovely to be here." Her eyes sparkled in memory. 
Later, Lára described the 2 to 3 hour walk she and others took to and from boarding school. They carried "mill sacks" filled with clothing, linens, and books to last the two weeks until they walked back home. Then, their mill sacks held laundry for washing before school resumed. About the long walk she said, "It was very nice. I liked it." My question about walking in the West Fjords' notably changeable, often extreme weather, brought a big smile and the comment, "I think it was always the good weather, always good weather. It was very nice."

The region's dirt paths and unimproved roadways follow contours of hummocked earth and rolling hills. Winds and breezes blow through canyons to enliven plants and spirits. Birds fly and settle, sound alarms and call to mates across open spaces. The air carries scents of plants, water and minerals. All are accentuated by changes in weather. Lára knew in muscle and bone, before and more deeply than in words, the rhythms and voices of living land and sea. These associated also with memories of agemates, elders and ancient stories in shared spaces. Such memories of place exceed describable experience and, neuroscience tells us, form the underpinnings of personhood by providing the neurological and conceptual foundations for abstract thought and empathy with people and spaces [3].

On the maps, Lára showed me the rivers and lakes "to be taken" for Hvalárvirkjun. She recalled and her face and posture reflected the shock of seeing for the first time colored shadings that indicated how the land, small lakes and rivers of Ófeigsfjörður and Eyvindarfjörður would change with the project. The plans, then only recently distributed via news outlets, included not only far more land, lakes and rivers than she had anticipated but also a sizable portion of her family's land and their river on Eyvindarfjörour. Several small lakes on their property would be combined to form a large reservoir.

Looking me straight in the eye, Lára said, "This is not their land; this is our land; we know, we have always known [her emphasis], [this land] belongs to our family." The depth of her connection to the land was as tangible as her desperation at the thought that it might be lost to all people forever. The family hired an attorney to prove that the land is theirs "and can't just be taken."

Lára recounted the subsequent discovery of two confrontations between tradition and modernity that left the family vulnerable to loss of their land. With an attorney's help, they documented their grandfather's purchase of the land in 1890 , but its upper boundary was ambiguous; the land extended to the edge of Drangajökull, a glacier that had since receded. Lára stated that all long-time Árneshreppur residents knew that her family owned and used that land continuously since 1890; none were commenting, including their neighbor on Ófeigsfjörður who leased to Hvalárvirkjun developers his water rights to two main rivers, Hvalá and Rjúkandi, and many small lakes critical to the project.

The second confrontation originated shortly before the public was fully informed about plans for Hvalárvirkjun. A wealthy Italian man approached Lára's brother about purchasing a small piece of the family's land for the purpose of harvesting wild blueberries that he planned to process in a small factory he would build onsite. The men negotiated a price and completed the sale. Shortly afterward, the purchaser claimed a much larger piece of Eyvindarfjörður than agreed and sold to Hvalárvirkjun developers water rights to the river, Eyvindarfjörðurá, and several small lakes on the property. The family contested the sale and discovered that legal documentation did not detail precisely enough the extent of the purchase as agreed to verbally. Lára, her family, and many others believed that this was the purchaser's plan from the beginning and that he had advance knowledge of project scope and renewal.

In the past and still in some remote areas, legal transactions relied at least partly on spoken agreements, traditional ownership, local knowledge, and personal ethics as much as precise written detail. The resultant, legally ambiguous property boundaries are behind the contested ownership of the section of Eyvindarfjörður of interest to VesturVerk/HS Orka. Such situations repeat globally in marginalized areas; a verbal agreement or handshake was binding until, motivated by outside corporations or individuals, monetary self-interests gained a foothold. Equally unfair is the associated denigration of sellers for their "backward, unsophisticated" ways rather than purchasers for their methods. It becomes, then, that much easier to dehumanize and ignore people who believe in the power of honesty and of relationships between people and to the land.

Lára said, "We are opposed to the dam because we would love to save the nature. This land here is one of the few areas in Europe where there is nothing. We HAVE to save it [her emphasis]... There's no one here." Lára reported her brother's sorrow at the unintended outcome of the sale and the possible loss of this unique area not only to the family but also to the planet. The quiet strength and modulated desperation of Lára's voice contained also sorrow that reflected in her eyes as tiredness, resignation and resolve and suggested her felt abandonment by people she cared about. A secondary outcome of this conflict was the great rift created within a once-close community. This was experienced as loss on both sides of the conflict.

Opposition to the project attracted international attention and support. Researchers at the University of Leeds, England, found that with Hvalárvirkjun the pristine wilderness of the Ófeigsfjörður heath would reduce by at least 45-48\% [4]. Similarly, the international committee of the International Union of Conservation of Nature concluded that a hydropower plant in this region would alter forever the hydrology and nature of the area that is among the few remaining wilderness areas in Europe. These findings are consistent with those of the Icelandic Institute of Natural History, but neither had substantive legal power [5].

VesturVerk continued to advance the project in cooperation with Árneshreppur. In this area where roads are closed from November to March and telephone and electric services are interrupted frequently in bad weather, the municipality was heartened by power company promises of improved roads, internet and telephone, and delivery of better electricity. 
However, changes to the plans suggested to Lára and others that the quality electricity that is needed will go elsewhere, bypassing Strandir and most of the West Fjords. In addition, roads were somewhat improved within part of Strandir but not the roads into Strandir. Year-round access to the region appeared no more secure.

Related concerns were repeated privately to me by many others. Several people likened VesturVerk's promises to Europeans' offer of glass beads in exchange for American Indians' land. National media quoted informed professionals who also questioned that Hvalárvirkjun would bring long-term benefit to the region [6]. While Lára understood dam proponents' urgent efforts to obtain power and access, she believed that with new sources of power (e.g., wind, wave and solar) on the horizon, temporary methods like diesel generators could be used until less destructive options become available.

Lára understood this place as a global treasure, unique in the world. More important to her than continued exclusive access of family to this natural setting was designation of the area as a nature preserve. This would allow many people to experience the earth "like it has been through time." To her, this was far better than seeing it destroyed for electricity that could be obtained by other means and for monetary gain by a few individual Icelanders and internationally owned companies. Behind closed doors, I heard similar sentiments from far more people than the varied, small percentages quoted to me by dam proponents.

Lára encouraged me to take the tour of the partially restored herring factory in Djúpavík, saying "They are very good at telling about it and Djúpavík. If you have time, you should take the tour." I discovered later that the factory owners and restorers who developed the tour are Eva and her husband, Ásbjörn. They are as strongly and outspokenly in favor of Hvalárvirkjun as Lára is opposed. On the way to meet Eva, land and sea revealed stories of their own.

\subsection{The Layered Setting of Hvalárvirkjun's Story}

My three-day trip to Árneshrepper began in Ísafjörður. For safety while hiking in the remote and to me unfamiliar Strandir region and for social and historical background, I travelled with bórður, a certified backcountry guide, third-generation farmer, and rural letter carrier in the areas visited. He provided balancing perspectives and background information and opened doors to spaces and conversations where I was unknown. His high-clearance, four-wheel-drive SUV was necessary for reaching some of the areas we explored.

We left Ísafjörður for Árneshreppur in a West Fjords-typical, autumnal drizzle that continued intermittently for the duration of the trip. Our destination for the day was the village of Djúpavík and its namesake hotel, where we spent the two nights. The six-hour drive left time to explore some of the area before dinner. The second day was devoted to driving to and hiking part of Ófeigsfjörður below where the dams were planned. This provided a sense of the terrain without requiring a two-day backpack to the proposed dam site.
In all, about three fourths of the first day's drive was on paved, increasingly narrow two-lane roads that wound fjords and mountains; traversed mountain tops, meadows and heaths; and zig-zagged down cliffs. We traveled past abandoned and occupied farms, small active and derelict fishing docks, and lodging and restaurants then closed either permanently or for the season. We drove across wide expanses of open land, through valleys of varied size, and past an occasional village. Road hugged coast at the bottom of many fjords, where at high tide sea licked or pounded shore near the road's edge. Increasingly evident with distance driven were deteriorating road conditions and ongoing population decline of humans and grazing sheep. I recalled a Reykjavik Grapevine news article that referred to Árneshreppur as "part of the other Iceland" in acknowledgement of the unique geographies of the district's spaces and its remove from basic benefits of national prosperity [6].

Landscape changed with distance driven. Most notably, the relatively smooth, boulder-laden upward sweep of mountainsides transitioned to benchland geomorphology. Where benches stepped up slopes and interrupted vegetation with vertical rock faces, the land looked terraced. When stone benches were not present, talus tumbled down steep mountains. Waterfalls shot over cliff edges from never-tamed rivers, silvered down steep slopes, and echoed through valleys. Never had I been in a landscape like this — not in Asia, North America, elsewhere in Europe or Iceland. Pórður observed that across these vast spaces we saw the history of the earth itself as it had evolved from its beginning.

Scenery revealed the natural and human history of this space. For three days, we lived a bit of each. Cloud-filtered sunlight intensified the colors of autumn. Reds, oranges, yellow, and the last bit of green stood out against a complexity of browning vegetation over gray to brown basalt. Under the dark, close sky, the sea grayed in color and sound as waves rocked the shore, hollowed against stones that it rolled and on which its foaming fingers crinkled and spread. Whorls where currents mixed showed turquoise both vibrant and deep, a metaphor perhaps for the love of place felt so strongly by those on both sides of this story.

This far north, the character of land and sea change in the light of closely overcast skies. Shadows settle in depressions, geological relief flattens, distances collapse and further distort already false perceptions of nearness. Land- and seascape become magnetic drawing you into their spaces and magical in the way they call to mind old stories of early settlers, myths and legends - images of a lone farmer-of-old leading a heavily laden horse across vast expanse, sheep dog at their side; a banished outlaw sheltered in hidden valleys, secluded among hills; a Ninth Century troll hunched and hurrying to escape the rising sun. We visited the hut where a well-known witch conjured spells not so long ago.

Stories, however fantastic, have emotional staying power and the historical orientation of cultural and spatial underpinnings. This landscape, especially in this light, supported them, their human-with-nature origins and lasting influence. Little wonder that people of places across Iceland, 
as in other little-tamed spaces, know the legends and sagas most closely associated with the spaces they frequent. These stories of old are alive on the land today and pass through families and communities over time.

Across evolutionary time, such spaces have inspired and required understandings and behaviors of inhabitants, thereby shaping Homo sapiens individually and collectively. With and through geography, humans evolved [7]. From neuroscience and archeology, we know that these spaces-become-places are critical in the evolution of all living things and of Earth. I felt the same empathy with them that I would feel later with people on both sides of the Hvalá conflict. Such emotional connection is critical in human development and evolution [3, 7].

At each transition within and between fjords, light, land, and seascape changed. This was noted frequently by Pórour, who attended to the geology, the land forms it supported and the humanmade alterations that it allowed. For Pórður, geology told stories of Earth, and Earth allowed only certain human stories to be told with and on it. Alluding to the fact of limited human power and insight, he said, "The earth decides what can be built and last here"- a variation on the oft-heard Icelandic theme, "No one controls nature." Nowhere is this more abundantly clear than the remote areas of this modern, long-lived island nation.

We met little traffic. On our final approach to Djúpavík, the pavement crumbled and gave way to gravel. Waterfilled potholes grew in frequency and size. The shoulder narrowed and muddied, ruts deepened. Parking to avoid mud and water-filled depressions in front of Hótel Djúpavík required consideration. We stood for a minute to survey our surroundings.

The two-story hotel sat long and low, inobtrusive but welcoming within the space, dwarfed by the steep mountain behind. To the left, the historic, long-retired herring factory was a massive, once ultra-modern testament to Icelandic determination, resourcefulness and commitment to place, and also to nature's intervention in human plans. High above us, a waterfall poured furiously over a long vertical drop. It splayed and split against the sharply angled edge of a tall rock outcropping in its path. Behind us, the sea lapped a grounded ship's dissolving metal hull. It served once as housing for men who worked at the herring factory.

Eva and Ásbjörn, the hotel owners, repurposed the former women's dormitory as Hótel Djúpavík. They transformed also the abandoned factory into a museum and art center. When completed in 1935, the factory was the largest concrete building in Iceland and among the most modern factories in Europe. Ninety meters long and three stories high, the state-of-the-art-factory processed herring into fish meal and filtered fish oil, 5,600 tons of it stored in heated tanks nearby. Remarkably, the entire structure was completed and operating within one year even though all construction materials arrived by ship and were transported from ship to construction site by human labor alone. There were no roads to or within Djúpavík at that time.

Production was high and sales strong until herring stocks declined dramatically. The factory closed in 1945. Subsequent attempts to repurpose the factory were unsuccessful. It closed permanently in 1954, but its story lives on across Iceland. Centuries old farming communities continued in the region.

When Eva and Ásbjörn first visited in the mid-1980s, they found a deteriorating factory and the close-knit community that have been central in their lives since then. They believed that the old factory and hotel could become both significant historical markers for the country and destinations for tourists. A new business plan was born. To attract people to the area, build community and raise funds for continuing renovations, the factory became a dramatic venue for popular music groups, artists, and art shows.

\subsection{Eva's Story}

Eva's commitment to traditional Icelandic values and graciousness was apparent as soon as we entered the hotel. The front door opened into a large dining-reception area where memorabilia from community, sea and mountainsides lined the walls. The aged plank floor was notably free of mud and gravel. Coffee, tea, and cake, typical offerings of a gracious Icelandic home, were readily available to guests all afternoon on a long table and buffet chest near the door. At the near end of the room, a desk and table or two served as the office. Eva came from there to greet Pórður and meet me. She sat down with us to visit, and the two resident dogs stopped by to investigate while we talked. I felt like we had stepped into a family or community living room.

Eva told me that she and Ásbjörn bought the factory and associated buildings in 1985 after "falling in love with the area" during a casual visit. Nearly 35 years later, a hint of tenderness in her voice and a slight smile suggested that Eva remembered this first love of place that has deepened and matured over time. They lived in Djúpavík since then, raised their children there, managed the inconveniences of life in remote place, and contributed to the community in various ways. This widespread but close-knit community was among the most treasured qualities of the municipality they knew. They valued also the availability of high quality wild and domesticated foods nearby and the beauty of the setting in which all of this thrived.

As two-term chair of the Árneshreppur council, Eva was active in the district's economic development efforts. These included sustaining local fishing and farming, attracting outside businesses and tourists to the area, and revitalizing the sagging feeling of inclusive community valued by its members and visitors on both sides of the conflict. Personally, Eva sought stability for her own tourist-dependent business and, even more, continued life in a place she loved, that shaped her and her family, and that they helped shape across decades. With an urgency similar to that of Lára's, Eva stated that the successful completion of Hvalárvirkjun was the last hope for saving the community before it dissolved forever. When asked what she so loved about Djúpavík and Árneshreppur, Eva replied, "It's home!" Her words were sudden and sharp, a plea and a cry.

Eva explained that there was not enough time left to wait for alternatives to hydropower. The community was fading too 
quickly and national approval for new approaches took too long. Communities and their cultures cannot simply reestablish later when power becomes available. They must grow, people and place together, over time. Starting anew without firsthand, historical knowledge of people and place results in an entirely new culture that is slow to emerge and less sensitive to natural rhythms and needs [8]. Understanding of this flickered briefly as fear across Eva's face and fueled her nearly desperate belief in the promises made by the VesturVerk company.

Eva's strength in the continued battle for electricity was impressive. She recalled that a year or two earlier one of the dam opponents posted on Facebook that the hotel was dirty and that the food had made her sick. A check of hotel records revealed that the woman had never been there. Finishing this clearly painful story, Eva quickly squared her shoulders, straightened her back and stressed again the necessity of good roads and power for Árneshreppur. She became, then, not only the two-term chair of the municipal council but also a defender of the values and histories that made Iceland, this region and these people strong, resilient conservators of their geographical spaces. Eva neither bemoaned nor criticized the offender. Later in Reykjavík, I learned that Lára was unaware of the post in advance and was distressed by it and the pain it caused. The two women, both of this community, felt the many actual and potential losses as the rift widened and the land changed in advance of the dams.

In this often-isolated area, life was made possible and warmly personal by the felt interdependence and mutuality of people with each other and the space that held them. Conflicts and compromises arose with respect for the personhood of the other and an eye to the community in meaningful space. Personal meanings of belonging to this place derived from the interpersonal, natural and historical setting, wove through Eva and Lára's personhood and that of their families. Both women felt the void of its absence in more anonymous spaces and when conflict created, as now, a great divide. Unlike Lára, Eva believed that the rift opened by the Hvalávirkjun conflict was too wide to bridge. In the absence of compromise options, it differed from heated and healed community conflicts of the past and required permanent winners and losers.

The second day in Árneshreppur was devoted to Ófeigsfjörður. On the way there, we saw the school that VesturVerk agreed to renovate for eventual use as a hotel, and we passed earth-moving equipment at work on the road between Djúpavík and the construction site. Tracks of this equipment formed deep, muddy grooves up the hillside. Pórður rolled down his window to visit briefly with the workers and explain our presence, a curtesy that he repeated with farmers and others throughout our travels around Árneshreppur.

At the bottom of this fjord, tree-sized drift logs from Norway or Siberia rested on a muddy, low-tide beach. In earlier days, they would have been milled and used for lumber. On the beaches of deep and narrow fjords, bórður identified the entire history of Icelandic fishing in the detritus - early glass floats, later iron bobbins, then varied rubber equipment, and newer plastic for many purposes. From this road, we saw Drangaskörð across the water. The basalt monoliths became more distinct and more intriguing as we drew closer to them.

Such geographical and historical markers increased as we moved deeper into Strandir. The road narrowed and lost most of its thin gravel layer. The scenery became more dramatic, the road more a part of it. Where human-made structures existed, they situated on available patches of mostly flat land against steeply rising mountainside or jutting outward toward the sea. Occasionally, a car, truck, or tractor sat near houses and outbuildings. All were dwarfed by their surroundings. We saw no activity to suggest occupation, no dogs or sheep in yards, no other cars on the road, no laundry on clotheslines, children playing or adults working even on the mostly rain-free day. Once the homes of year-round farmers, these were now the houses of part-time, summer residents who had returned to cities for the season. The scene felt diminished, lonely, and fleeting.

The road became two tire tracks through a meadow. We drove on, passed more drift timber (weathered roots still present), and forded a fast-moving river of tide-controlled depth just above its entry to the sea. Where the tire tracks ended at a wooden footbridge, we left the truck and started hiking. Beneath the bridge, a larger river roughed and raced over a carved rock bed, widened where slope decreased and banks transitioned to soil and grasses. It swirled, finally, into the sea. On the uphill side, this river plunged wide and fast over a basalt bench to form a waterfall mesmerizing in deep clarity and intimidating in power. Six hours of hiking began here and was limited only by the need to return in advance of high tide.

There were no trails. We stepped with care, on rock when possible, to minimize harm to fragile vegetation. We saw two or three human footprints, some evidence of sheep and an enormity of tiny mosses, lichens, trees, bushes, sedges and more. Knowledge of their medicinal and nutritional value had handed down locally generation to generation, but Pórður felt the loss of much of this knowledge as daily distancing from the land increased between his generation and that of his father. To make ends meet, Pórður had given up daily farming practices to pursue simultaneously several alternate forms of employment. He gathered a small sample of plants to send home with me for tea and seasoning. In this gift from land, place and person, I recognized my privilege and rural Icelanders' generosity and deep love of place.

The terrain was rough, no straight or obvious route to anywhere. We gained or lost elevation only where vertical drop diminished at the sloped ends of basalt benches. Progress was as much horizontal across flat bench tops as vertical. Way-finding required knowledge beyond awareness of three-dimensional distances and spaces bounded by geological forms. The literal groundwork for such cognitive skills and, later, abstract thought is laid by physical experience in spaces like these [3]. Similarly, complexity of soundscape supports development of evocative and differentiated language [9].

Differences in scale and diversity in detail were striking. 
Sightlines expanded across land, sea and sky. Geography alternately exposed and enfolded us. Under foot, minute vegetation was intricate and varied. At a distance, delicately filigreed, stark white reindeer lichen glowed against textured backgrounds of rock, dirt and moss. Lára's affinity with this community of plants, animals, and geology became increasingly comprehensible.

Rushing water filled canyons rim to rim, bright rainbows formed in waterfalls' mist, individual water droplets bounced off rocks to hang in air before falling back to long roiling rivers. Distant clouds cast shadows on ground and sea, released water as pin-striped virga. To cherish such land is to appreciate differences and harmonies of scale and to comprehend nature as one interactive system that includes the animate and inanimate - animals (including human), plants, minerals and more in their many configurations and equalities [10].

These spaces held a mutuality of individuals, human and more than human, grown and evolved together across centuries. Words, sensations, emotions and shared understandings combined to make the space meaningful place for those who knew it. The depth and breadth of their fear and sorrow was understandable; a terminal blow to any part threatened the whole and the foundations of person and place.

On the drive back to Djúpavík, I felt the loneliness of this remote place intensified by the subtraction of people from spaces once occupied. Something else was missing, too; I struggled to identify that other element until I realized that I had seen no sheep all day. Across rural Iceland, sheep enliven spaces as, widely scattered, they graze hillsides, grasslands and seashore. They have helped to shape land, culture and life. The landscape was different without these partners in the co-evolution of people and place.

Knowing well the potential impact of sheep on vegetation, I surprised myself by saying to Pórður, "These hillsides need their sheep." Pórður acknowledged this observation with a nod. Later, Eva added that some residents believed the grass had been slow to green that summer because without the sheep too much old grass remained. Árneshreppur was clearly changing and the few remaining full- and part-time residents were willing to change with it as needed to continue in place. The disagreement was over how to save its most treasured qualities.

Eva noted that landowners who were summer-only residents and dam opponents didn't understand that the place they loved would change necessarily and unpredictably when the year-round community was gone. As a nature preserve, the Árneshreppur they knew would fade rapidly in generational memory to become a less personal, more public space [11]. Evolution would take different directions without farmers, sheep, fishing and families. Eva's choice of community over nature was a last-ditch effort to preserve as much as possible of the co-mingled space and place that she valued.

Lára established contemporary community in Reykjavík, but her foundational memories were of Árneshreppur as an Earth-aged, integrated and evolving system of human and nature together. She believed that the wounds of the hydropower conflict would heal in time, but she knew that if Hvalárvirkjun progressed, one of the last remnants of Earth left mostly to its own evolution would be gone forever. This was a loss that she could not bear for herself and for others worldwide. With a forced choice between her original community and these unique spaces, Lára chose to preserve the spaces.

\subsection{Gunnar's Story}

As co-founder and director of VesturVerk, the company responsible for designing and building Hvalárvirkjun, Gunnar oversaw the project's development, water rights acquisitions and early construction phases. He grew up in the West Fjords, moved away to complete a degree in mechanical engineering, and then worked three years in Canada in the shipping industry before returning to Ísafjörður. Well aware from personal experience of the need for reliable, three-cycle electricity, good roads, and telephone and data services in the West Fjords, he established VesturVerk to design and build a hydropower plant with the least possible disruption of nature. In his words, "Nature was the primary concern and the need for safe [meaning reliable] power the driving motivation."

Gunnar and I met on September 25, 2019, in the conference room of his modern, second floor offices that overlooked Ísafjörður's commercial center and town square. He described plans for Hvalárvirkjun and their evolution across several public reviews and environmental studies. Five dams were planned on Ófeigsfjarðarheiði; a sixth dam was under consideration. The largest dam, on Hvalá (the river), would be 28 meters high and, he said, not visible from below. The remaining dams "would be not so noticeable." Three existing lakes would be enlarged but not merged. Underground tailraces would connect lakes and the three rivers. Controlled water flow would ensure year-round water in rivers and waterfalls - a tourism and, thus economic, development consideration. Gunnar's approach was a compromise and a thoughtful design that reflected a genuine concern for both nature and the serious regional need for electricity.

He acknowledged that even with this care, there would be disruptions to nature and people's response to it. He expressed also concern for the viability of the West Fjords if high quality, reliable electricity remained unavailable and noted that the current reliance on supplemental energy from diesel generators was neither economically nor environmentally sustainable. The situation had caused the loss of some businesses and prevented establishment of others.

Gunnar referenced also the denigration of the West Fjords by many people across the rest of the nation that makes it easy to ignore the needs and contributions of the region and to impede regional development efforts. A long history of such marginalization leaves the West Fjords with few options beyond finding ways to solve central problems themselves using their own, internal resources. They are notably resourceful and resilient in this and attentive to issues of economic, environmental, and cultural sustainability.

As originally conceived, the power plant would supply from within the region the West Fjords' electricity needs 
before surplus power was sold elsewhere. This was not entirely within VesturVerks' purview, however. VesturVerk was responsible for power generation, but another company, Landsnet, owned installation rights for electric lines across Iceland. Landsnet's plans included only a line to transmit the new electricity to the main power distribution system for the rest of Iceland, not including the West Fjords. Gunnar noted that this was beyond his control.

Similarly, Gunnar turned to HS Orka, the Swedish company, only after his funding efforts proved unsuccessful with West Fjords and national power companies. Although he was retained as project director when HS Orka assumed majority ownership of VesturVerk, Gunnar's control of the project seemed to diminish with each step toward construction and operation of Hvalárvirkjun.

Trust of Gunnar and his co-founder (both described as "local boys") was strong within the region, but several people expressed concern privately about the involvement of HS Orka. Their concerns were underscored when on July 5, 2020, HS Orka announced the closure of VesturVerk and postponement of work on Hvalárvirkjun due to economic instability and decreased international demand for power from Iceland [12]. In addition, HS Orka cited findings from their own research and within Iceland that enough power was already generated within the country to supply its own needs. HS Orka did plan to continue research at the dam site, however.

With VesturVerk gone, Gunnar resigned his position but remained on the HS Orka board of directors. Water rights on Ófeigsfjarðarheiði remained with the Swedish company that may or may not continue efforts toward Hvalárvirkjun as originally conceived. Ownership of water rights to Eyvindarfjörðurá are still contested through the Icelandic legal system.

\section{Discussion}

The stories told by Lára, Eva, and Gunnar all drew from the same national and regional narratives. The individual stories differed, though, because each represented a constellation of sensation, emotion, behavior and knowledge unique to the individual storyteller. Each story grew from a different history and generated a different perspective on what future should be pursued. A common thread, clarified by including Earth as storyteller, ran through all of the stories. This thread, so basic to human functioning that it is easy to overlook, wove through the Hvalárvirkjun conflict, extended it through history and into the future.

At its heart, this conflict was a matter of individual and species identity, how it develops and evolves individually and culturally and also the critical role played by other-than-human forces in this process. Spaces (physical environments) were imbued with meaning as they were acted on and folded into human stories over time. The resulting places were frequented materially in person and, later, symbolically as stories, thereby becoming the first sensuous experiences and abstractions of personhood. They formed the foundation for subsequent development and knowledge structures that expand and adjust to accommodate new information $[3,7,9]$. Stories not only ground identity in place but also weave through the stable structure of a self.

For people who know a place of nature, it grows with the self and in the heart. Their very being grows into the place, is expressed there, invests in land and sea, changes spaces as person is changed by those evolving contexts across days, seasons and years. With identities enmeshed, they become each other in central ways, separate and interwoven. Such connections last a lifetime, foster human membership as part of all nature, and used to hand down from generation to generation.

This blending of self with place lends understandable life-or-death intensity to threats to place in whole or in part. The intensity of conflicts like those surrounding Hvalárvirkjun initiates here, as do the motivations and courage necessary to persist in defense of place. From a wider view, a critical question asks: "What happens to Homo sapiens" psychological, emotional, and intellectual evolution when identity and community are no longer linked to Earth, when these are shaped primarily by human artifacts?" We know already what happens to Earth.

In spaces like those of Strandir, the dynamics of nature dominate; people live and adjust within them. Dominant textures, sounds, odors, daily and annual rhythms are nature's gestures that shape thought in ways similar to human gestures. They add complexity, novelty and diversity of scale; introduce dynamics beyond the human; require physical activity, flexibility and complexity of thought, awareness of limits to human power, and appreciation of the more-than-human. In this, these places are enriched and enriching [13]. They differ from enrichments of human-built, urban environments in their frequent reminder that the planet supports many and has agency of its own. For many residents and visitors of little-tamed spaces, this reminder supplies aesthetic and spiritual connections to Earth beyond those of human-dominated spaces $[8,9,13]$.

\section{Conclusions}

There are numerous and obvious implications for efforts toward resilient and durable futures. Such futures require strengthened human-human and human-nature relationships and practices of science, especially social science, that admit close, integrative study of these relationships. Similarly, economics, laws, policies and regulation must support development of such long-term relationships. This must become one criterion against which new and existing regulations are evaluated [14-17].

Importantly, these findings do not suggest that all wild spaces should be set aside as nature preserves. Such areas are too often commercialized, promoted and gentrified for access by expanding numbers of tourists who come more for entertainment than knowledge of these spaces, their physicality and history and the varied life forms they sustain [11]. Emotionally and intellectually, this is as much a loss to 
the planet and Homo sapiens as loss of land- and seascape [13, 18]. Under those circumstances, human-nature relationships cannot establish and human community is hampered by, among other things, competition for prime viewing or income generating spots, brevity of time in spaces, and absence of established community cultures and the arts of daily living.

While the intensity of the Hvalárvirkjun conflicts centered around threats to place and, thus, to collective and individual identity, the absence of compromise possibilities violated regional cultural values and practices and further intensified the conflict. Even with Gunnar's thoughtful, nature-sensitive design of Hvalárvirkjun, significant disruption to nature and community will result. No effective alternative to hydropower and its irreversible effects was available in the foreseeable future. The resultant, forced dam-no-dam choice divided the community and extended across the nation. A quick review of geo-political super powers reveals ways in which such divisiveness initiates, develops and spreads globally [16, 19].

In this case, a regional and national issue also brings into focus growing attention to locations that might be considered part of a continental or worldwide commons and suggests questions that apply equally to such spaces globally (e.g., rainforests, the Amazon River, outer space and, even, 5G networks and communication technologies). Questions accumulate around sovereignty and responsibility; international communication and community; development of human qualities, values, cultures, and knowledge necessary for cooperation and collaboration; strategies for arriving at compromise and equity across cultures and geographies; continued development of institutions of sufficient scope and skill to facilitate compromise; and identification of which nested organizational level is best positioned to facilitate conflict resolution efforts.

In addition, the types and sources of information admitted as critical considerations for these discussions must receive particular attention. Ignored far too long have been the intimate, traditional knowledge of people of place; the emotional knowledge of place and self that is experienced and demonstrated by diverse residents of place; and the characteristics shaped by material, intellectual, and emotional environments that humans create. There are implications here for legal, economic and policy-related systems and for the disciplines that inform them; the questions asked, methods used to answer questions, and formats for sharing those answers require attention.

In the case of Hvalárvirkjun, the conflict could not be resolved within Strandir or the West Fjords despite their history of community compromise and effective local problem solving. This problem initiates and continues in the exclusion of these areas from the national three-cycle electricity transmission grid. I asked often why transmission lines were not extended to include the whole of the West Fjords and heard repeatedly the same two reasons: "We are too few. They don't want to bother with us," and "It's too expensive and difficult to extend the lines, because to withstand ice, high winds and avalanches, they will have to be underground." With no local alternatives available, this seems to be a conflict that can only be resolved at the national level.

With similar situations worldwide, exploration of new roles for regional and national governments as partners in resolving such issues seems wise. A growing body of work strongly suggests that resilient, durable futures are best served by helping localities build resilience and economic stability in place $[14,17,20]$. Such next-level assistance must take the form of collaborative problem solving with the people of place and may include a pooling of multi-level resources of various types. Relatedly, evidence accrues globally in favor of support for extant, traditional food production methods that respect Earth and its many inhabitants while also providing reliable supplies of food, water and medicinal herbs. The resultant felt mutuality of coevolution was behind my awareness that the hillsides of Árneshreppur "need their sheep."

One additional issue stands out among the many globally relevant concerns comprised by the Hvalárvirkjun conflict. It relates to capitalism, globalization, colonization, and geopolitics and, too often, international actors' self-interested power-wielding and -grabbing. This serious global concern and the extensive reach of its effects were presented to me multiple times. Many such comments referenced the low prices charged for foreign use of Iceland's clean energy, but a particularly poignant comment during my Strandir visit related to food security and expressed also the feeling of many Icelanders for the cohabitants of their places.

Referencing the decline in Iceland's cod fisheries, one man said, "We had beautiful, well-caught fish of better quality than almost anywhere in the world, and we just took their souls, hung them to dry, and ground them into fish meal that was exported for less than they were worth." Evident in this comment were his deep sadness at the inherent disrespect of place and concern for the future of a country that sells its resources without seeing first to its own long-term needs and historical identity. A similar situation exists in the gradual abandonment of sheep farms where bad roads and power failures undermine the viability of farming.

The person quoted understood simultaneously, though, Iceland's position in global context. Export, especially of renewable resources, is critical to the future of countries that must rely on imports for many of their needs and that must use their unique resources to establish their own secure economic bases. Further, powerful allies are critical for small countries that are relatively new players on the international scene. The resultant vulnerabilities are easily exploited by more globally powerful countries [19]. The climate change induced opening of the Arctic only increases the vulnerability of countries in that region. Many countries rush in to claim a share of it for themselves. These are growing, international issues in need of attention. Their resolution will require policy and legal structures that support frequent review and revision of regulations in response to changing conditions and politics and in light of developing knowledge and insights.

As more nations see landmass and resources dwindle in the face of climate change, vulnerabilities spread. If we cannot regain a sense of partnership and mutuality with Earth and its incredible diversity of human and other inhabitants, these 
abuses will continue to harm us all. Incumbent on everyone are renewed efforts to explore our origins on our home planet, learn how it has shaped Homo sapiens, and decide not only if we hope to continue as that species but also how we can best see to the survival of the planet and all who share it.

The expansion of social science to include national and international context, meaning making, personal experience and nature as a fourth storyteller, offered deeper and broader understandings than anticipated. Lára, Eva, Gunnar, Pórður and many others across Iceland proved generous and able research partners. They helped to reveal social science as part of the continuing human story in a world made dynamic by both the flowing connections between things animate and inanimate and evolution at scales that range from tiny to large beyond imagining. Similar perspectives must be fostered and supported by legal, education and policy-making institutions.

It seems that all areas of human endeavor might grow in perceived relevance if they, too, were reintegrated into the always developing human story, if they strove toward open system functioning that admitted divergent information and embraced as a matter of course collaborative problem solving and responsive regulations. One thing is certain: As we go through our days, while we work each within our own disciplines and localities, we must remember that this is one world. We all live or die together with it.

\section{Acknowledgements}

J. L. S. thanks the people of Iceland, especially the people of the West Fjords, for their participation as partners in this research, their openness and hospitality, and their willingness to answer seemingly endless questions often with documentation included. Special thanks to the people named in this paper, to participants in the larger and longer study that initiated in 2013, and to the University Centre of the West Fjords (Háskólasetur Vestfjarða) in Ísafjörður, where I have always found hospitality, information, and opportunity to explore diverse perspectives.

\section{References}

[1] C. Callison (2014). How Climate Change Comes to Matter: The Communal Life of Facts. Durham and London: Duke University Press.

[2] B. Czarniawska (2004). Narratives in Social Science Research. Thousand Oaks, CA: SAGE Publications.

[3] B. Tversky (2019). Mind in Motion: How Action Shapes Thought. New York: Basic Books.

[4] A. Y. Valsson (2019, Nov. 26). "The greater impact of Hvalarvirkjun on uninhabited wilderness" ["Benda á meiri áhrif Hvalárvirkjunar á óbyggð viðerni”]. RÚV. Retrieved from https://www.ruv.is/frett/benda-a-meiri-ahrif-hvalarvirkjunar-aobyggd-viderni. Accessed June 7, 2020.

[5] A. Elliott (2020, May 2). "International conservation agency against new hydro dam". RÚV. Retrieved from https://www.ruv.is/frett/international-conservation-agency-aga inst-new-hydro-dam. Accessed June 10, 2020.

[6] A. Fontaine (2018, July). "Songs of the damned: Hvalárvirkjun and the future of Árneshreppur”. Grapevine Magazine.

Retrieved from

https://grapevine.is/mag/feature/2018/07/13/songs-of-the-dam med-hvalarvirkjun-and-the-future-of-arneshreppur/. Accessed Sept 24, 2019.

[7] G. Vince (2020). Transcendence: How Humans Evolved through Fire, Language, Beauty, and Time. New York: Basic Books.

[8] C. Wohlforth (2010). The Fate of Nature: Rediscovering Our Ability to Rescue the Earth. New York: Picador.

[9] D. Abram (1996). The Spell of the Sensuous. New York: Vintage Books.

[10] A. Goodbody (2011). "Sense of place and lieu de mémoire: A cultural memory approach to environmental texts," in Ecocritical Theory: New European Approaches, A. Goodbody and K. Rigby, Eds. Charlottesville, VA: University of Virginia Press, pp. 55-67.

[11] L. A. Watt (2017). The Paradox of Preservation: Wilderness and Working Landscapes at Point Reyes National Seashore. Oakland: University of California Press.

[12] BB Newspaper (2020, July 5). "VesturVerk Resigns and Closes The Office," ("Vesturverk segir upp og lokar skrifstofunni,"). Downloaded from http://www.bb.is/2020/05/vesturverk-segir-upp-og-lokar-skrifs tofunni/ on July 6, 2020.

[13] H. L. Kristjánsdóttir, S. Sigurðardóttir, and A. M. Pálsdóttir (2020). The restorative potential of Icelandic nature. International Journal Environmental Research and Public Health, 17, 9095. Doi: 10.3390/ijerph17239095.

[14] B. McKibben (2007), Deep Economy: The Wealth of Communities and the Durable Future. New York: St, Martin's Press.

[15] B. McKibben (2019). Falter: Has the Human Game Begun to Play Itself Out? New York: Henry Holt and Company.

[16] A. Ghosh (2016). The Great Derangement: Climate Change and the Unthinkable. Chicago: University of Chicago Press.

[17] C. Eisenstein (2011). Sacred Economics: Money, Gift and Society in the Age of Transition. Berkeley, CA: Evolver Editions.

[18] B. C. Lane (2001). Landscapes of the Sacred: Geography and Narrative in American Spirituality. Baltimore: Johns Hopkins University Press.

[19] R. Andersson (2019). No Go World: How Fear Is Redrawing Our Maps and Infecting our Politics. Oakland, CA: University of California Press.

[20] Food and Agriculture Organization of the United Nations, International Fund for Agricultural Development, UNICEF, World Food Programme, and WHO (2018). "The state of Food security and nutrition in the world: Building climate resilience for food security and nutrition." In The Food and Agriculture Organization of the United Nations. The State of the World Series. Rome: FAO. Downloaded from fao.org/3/I9553EN/i9553en.pdf on January 13, 2021. 